\title{
Effects of a Mat Pilates Programme on Body Composition in Elderly Women
}

\author{
M Fourie $^{1}$, GM Gildenhuys ${ }^{1}$, I Shaw ${ }^{1,2}$, BS Shaw ${ }^{1}$, AL Toriola ${ }^{1}$, DT Goon ${ }^{3}$
}

\begin{abstract}
Background: With ageing, the ability to mobilize fat is reduced and this, coupled with gradual decrease in lean body mass (LBM) from lessened exercise, allows for an increased body fat percentage (\%BF). Exercising is considered a key to maintaining an appropriate body mass (BM), as it improves fat oxidation, while maintaining LBM. Although the effects of endurance and/or resistance training on fat mass (FM) and LBM in the elderly have well been established, limited data are forthcoming regarding the effects of Pilates as a training modality on these variables in the elderly.

Objective: The present study was therefore conducted to determine the effects of a mat Pilates programme on body fat in elderly women.

Methods: Fifty sedentary, apparently healthy females aged 60 years and older were randomly assigned a control (CG, $n=25)$ or an intervention (IG, $n=25)$ group. The IG took part in an eight-week progressive mat Pilates exercise programme, three times weekly while the CG were instructed to maintain their normal daily activities throughout the eight-week experimental period. All subjects underwent pre- and post-test in which FM and LBM were assessed.

Results: Eight weeks of mat Pilates demonstrated a significant $(\mathrm{p} \leq 0.05)$ decrease in $\% B F(\mathrm{p}=0.016)$ and $F M(p=0.038)$, with a significant increase in $L B M(\mathrm{p}=0.006)$, while not showing any significant changes $(\mathrm{p} \geq 0.05)$ in $B M(\mathrm{p}=0.979)$ and $B M I(\mathrm{p}=0.992)$. The CG, however, did not produce any significant $(\mathrm{p} \geq 0.05)$ changes in any of the tested anthropometric variables $(B M: \mathrm{p}=0.266 ; B M I: \mathrm{p}=$ $0.123 ; \%$ BF: $\mathrm{p}=0.516 ; F M: \mathrm{p}=0.937$ and LBM: $(\mathrm{p}=0.522)$ after completion of the eight-week Pilates programme.

Conclusion: An eight-week mat Pilates exercise programme may contradict or even reverse some of the most serious consequences of ageing associated with an increased fat mass and reduced lean body mass in elderly females.
\end{abstract}

Keywords: Aged, alternative medicine, anthropometry, complementary medicine, elderly, exercise

\section{Efectos de un Programa de Pilates de Ejercicios Sobre Alfombra en la Composición Corporal en Mujeres de Edad Avanzada}

\author{
M Fourie ${ }^{1}$, GM Gildenhuys ${ }^{1}$, I Shaw ${ }^{1,2}$, BS Shaw ${ }^{1}$, AL Toriola ${ }^{1}$, DT Goon ${ }^{3}$
}

\begin{abstract}
RESUMEN
Antecedentes: Con el envejecimiento, se reduce la capacidad de movilizar la grasa y esto - junto con la disminución gradual de la masa corporal magra (MCM) por la falta de ejercicios - hace que aumente el porcentaje de grasa corporal $(\%$ GC). La realización de ejercicios se considera clave para mantener una masa corporal apropiada (MC), ya que mejora la oxidación de las grasas, a la par que mantiene la masa corporal magra (MCM). Aunque los efectos de los entrenamientos de fuerza y/o resistencia sobre la masa grasa (MG) y la masa corporal magra (MCM) en las personas de edad han quedado bien establecidos, se presentan datos limitados con respecto a los efectos de Pilates como una modalidad de entrenamiento, sobre estas variables en los ancianos.
\end{abstract}

Objetivo: El presente estudio se realizó, por tanto, para determinar los efectos de un programa de

From: ${ }^{1}$ Department of Sport Rehabilitation and Dental Sciences, Tshwane, University of Technology, Private Bag X680, Pretoria, Gauteng, 0001, Republic of South Africa, ${ }^{2}$ Office of the Deputy Pro Vice-Chancellor: Research, Monash South Africa, PO Box X60, Ruimsig, 1725, Republic of South Africa and ${ }^{3}$ Centre for Biokinetics, Recreation and Sports Science,
University of Venda, X5050, Thohoyandou, Limpopo, 0590, Republic of South Africa.

Correspondence: Dr DT Goon, Centre for Biokinetics, Recreation and Sports Science, University of Venda, X5050, Thohoyandou, Limpopo, 0590, Republic of South Africa. E-mail: daniel_goon2004@yahoo.com 
Pilates de ejercicios en alfombra, sobre la grasa corporal en las mujeres mayores.

Métodos: Cincuenta mujeres sedentarias, aparentemente sanas, de 60 años o más, fueron asignadas aleatoriamente a un control $(C G, n=25)$ o a un grupo de intervención $(I G, n=25)$. El grupo IG tomó parte en un programa de Pilates de ejercicios progresivos sobre alfombras, de ocho semanas de duración, tres veces por semana, mientras que a los miembros del CG se les instruyó que mantuvieran sus actividades diarias normales durante todo el periodo experimental de ocho semanas.

Resultados: Las ocho semanas de ejercicios de Pilates sobre alfombra, mostraron una disminución significativa $(\mathrm{p} \leq 0.05)$ en $\% G C(\mathrm{p}=0.016)$ y $M G(\mathrm{p}=0.038)$, con un aumento significativo en $M C M$ $(\mathrm{p}=0.006)$, mientras que no se mostraron cambios significativos $(\mathrm{p} \geq 0,05)$ en $M C(\mathrm{p}=0.979)$ y el $\operatorname{IMC}(p=0.992)$. Sin embargo, el GC no produjo ningún cambio significativo $(\mathrm{p} \geq 0,05)$ en ninguna de las variables antropométricas sometidas a pruebas (MC: $p=0.266 ; I M C: \mathrm{p}=0.123 ; \% G C: \mathrm{p}=$ 0.516; MG: $\mathrm{p}=0.937$ y MCM: $(\mathrm{p}=0.522)$ luego que se completara el programa de Pilates de ocho semanas.

Conclusión: Un programa Pilates de ocho semanas de ejercicios sobre alfombra puede contradecir o incluso revertir algunas de las más serias consecuencias del envejecimiento asociadas con aumento de la masa grasa y reducción la masa corporal magra en mujeres de edad avanzada.

Palabras claves: Envejecido, medicina alternativa, medicina complementaria, antropometría, edad avanzada, ejercicio

West Indian Med J 2013; 62 (6): 525

\section{INTRODUCTION}

In addition to its enormous impact on an individual's quality of life, obesity is a daunting health problem worldwide (1). However, the anthropometric standards derived from adult populations may not be appropriate for the elderly because of body composition changes that occur during ageing (2). In both men and women, important fat redistribution occurs between 45 and 54 years of age and in older women the increase in waist-to-hip ratio (WHR) mostly reflects a reduction of fat deposits in the hips (3). In general, the elderly have been found to have predominantly android-type (appleshape) obesity as fat accumulation is more at the abdominal region. According to Folsom et al (4), truncal and abdominal fat storage sites are considered the most dangerous and are closely linked with disease, and changes in waist and stature girths capture increased abdominal adiposity and sarcopenia, respectively (5).

Lei et al (6) and Perisinotto et al (2) also found that with ageing, stature decreases, mainly due to spinal deformity and thinning of the intervertebral discs, with an increasing trend of total fat mass (FM) and various anthropometric measurements including waist circumference (WC), body mass index (BMI), WHR and conicity index (CI), where age and gender have the important effect on influencing this relationship. With ageing, the ability to mobilize fat is reduced and this, coupled with gradual decrease in lean body mass (LBM) from lessened exercise, allows for an increased body fat percentage $[\% \mathrm{BF}](7)$. Nakagawa et al (8) found that not only does body fat increase significantly with age, but so does intramyocellular lipid content which is positively related to \%BF and WHR. Skinfold thickness measurements also decline with increasing age (9). In the study of Ballard et al (10), it was also revealed that with increasing age, body mass (BM) was less. This difference in BM was, however, attributed to significantly less total LBM rather than to less body fat. Ballard et al (10) stated that with increased age there is a simultaneous decrease in bone and LBM and the elderly should therefore be encouraged to maintain adequate LBM due to its association with bone mineral density and thus, risk of fractures.

Exercise results in many benefits, especially the improvement in FM and LBM (11-13). In addition to these more conventional exercise methods, Pilates is another nonconventional form of exercise that results in improvements in BMI and could reduce obesity (14). Pilates has also been shown to assist in the prevention of falls and recovery of injuries (15), especially in the elderly. However, despite the numerous popular press reports on Pilates, the existing scientific evidence for Pilates is limited (16). Therefore the aim of the present study was to evaluate the effects of a mat Pilates programme on body fat in elderly women.

\section{SUBJECTS AND METHODS}

A sample of 50 elderly female subjects ( $\geq 60$ years of age), selected from care facilities within Pretoria, Gauteng Province, South Africa, were randomly assigned into one of two groups using a random numbers table; with 25 subjects undergoing an eight-week mat Pilates programme (IG), while the other 25 subjects participated as a non-exercising control group (CG). The research protocol was approved by the Institutional Review Boards of the Tshwane University of Technology, Pretoria, South Africa and was endorsed by the International Physical Activity Projects (IPAP). Permission to conduct the study at the care facilities was obtained from the relevant facilities and all subjects signed a written informed consent form indicating all the advantages and risks involved in participation in the study. All subjects were required to obtain medical clearance prior to commencement of 
Table 1: Subject demographic data

\begin{tabular}{lcc}
\hline & $\begin{array}{c}\text { Non-exercising control group (CG) } \\
\mathbf{n}=\mathbf{2 5}\end{array}$ & $\begin{array}{c}\text { Mat Pilates programme group (IG) } \\
\mathbf{n = 2 5}\end{array}$ \\
\hline Age (years) & $65.32 \pm 5.01$ & $66.12 \pm 4.77$ \\
Body mass $(\mathrm{kg})$ & $75.19 \pm 14.78$ & $71.71 \pm 14.92$ \\
Body mass index (kg.m $\left.{ }^{-2}\right)$ & $29.32 \pm 5.44$ & $28.32 \pm 6.77$ \\
\hline
\end{tabular}

Values are means \pm standard deviation; $\mathrm{kg} . \mathrm{m}^{-2}$ : kilograms per square metre

pre-testing procedures. Both groups took part in identical pre- and post-tests. Subject demographics at baseline are shown in Table 1.

\section{Physical evaluation}

All subjects were required to undergo anthropometric testing prior to and at completion of the eight-week treatment period. Anthropometric measurements were conducted according to the protocol of the International Society for the Advancement of Kinanthropometry [ISAK] (17). Body mass was measured in kilogrammes on a calibrated medical scale (Mettler DT Digitol, Mettler-Toledo AG, Ch-8606 GreiFensee, Switzerland) to the nearest 0.1 kilogramme $(\mathrm{kg})$ and stature was measured to the nearest 0.01 centimetres $(\mathrm{cm})$ using a standard wall-mounted stadiometer with the subjects wearing minimal clothing and no shoes. Skinfolds of the triceps, biceps, subscapular and iliac crest were measured to the nearest 0.2 millimetres with a Holtain skinfold calliper (Holtain Ltd Crymych, UK). Body fat percentage was calculated using the equations of Durnin and Womersley (18) to determine body density and then substituted in the equation of Siri (19) to calculate body fat percentage (20) as follows:

Density $(\mathrm{g} / \mathrm{cm} 3)=\mathrm{c}-\mathrm{m}(\log \mathrm{SS})$

Where:

* $\mathrm{C}$ and $\mathrm{m}=$ standard age and sex-specific coefficients

* SS $=$ Sum triceps, biceps, sub-scapular and iliac-crest/supra-iliac skinfold measurements

Once body density was calculated, the Siri (19) equation was used to estimate body fat percentage:

$$
\begin{aligned}
& \text { Fat }(\%) \text { women }=[(5.01 / D)-4.57] \times 100 \\
& \text { Where: } \\
& \text { * } \mathrm{D}=\text { Density }
\end{aligned}
$$

Body mass index was calculated by dividing body mass by stature squared (weight/stature ${ }^{2}$ ) and expressed as kilogram per square metre $\left(\mathrm{kg} \cdot \mathrm{m}^{-2}\right)$. Fat mass was calculated by multiplying body mass by fat percentage, which was divided by 100 [body mass $\mathrm{x}$ (fat percentage/100)]. Lean body mass was calculated by subtracting body mass by fat mass [body mass $\mathrm{kg}$ - fat mass $(\mathrm{kg})$.

\section{Pilates programme testing}

Mat Pilates exercises and exercise prescription variables were determined in accordance with the guidelines of Worth
(21) in order to compile the supervised mat Pilates exercise programme with all sessions being conducted by a Pilates instructor registered with the South African Pilates Association and certified in essential, intermediate and advanced equipment and mat. The periodized, eight-week Pilates programme consisted of three non-consecutive sessions weekly each lasting 60 minutes in duration. Prior to commencement of the programme, all subjects in the intervention group were trained on how to perform the Pilates exercises by a qualified practitioner. For each of the exercises, subjects were firstly familiarized with the exercise programme and then provided with simple step-by-step written instructions, an explanation of the basics of mat Pilates and an explanation of the neutral position of the spine and also the correct breathing techniques to be used during Pilates. All sessions began with breathing, followed by a flowing system from standing, to sitting, to lying down exercises and ended with the rest position (21). Non-exercising control group subjects were instructed to maintain their normal daily activities throughout the eight-week experimental period and were phoned three times weekly to ensure compliance.

\section{Statistical analysis}

Statistical analysis consisted of basic statistics to determine pre- and post-test means and standard deviations. A paired samples $t$-test was used to determine if a significant change took place in the measurements at post-test. Differences in measurements were compared by using a one-way analysis of variance (ANOVA) using a Dunnett T3 post-hoc analysis. Data were analysed using commercial software (Statistical Package for Social Sciences (SPSS) version 17, Chicago, IL) and statistical significance set at $p \leq 0.05$.

\section{RESULTS}

At pre-test, the groups were found to be homogenous for body mass $(p=0.412)$, BMI $(p=0.567), \% \mathrm{BF}(p=0.364)$, FM $(p=0.951)$ and LBM $(p=0.061)$. Following the eightweek mat Pilates programme, the IG demonstrated a significant $(p \leq 0.05)$ decrease in $\% \mathrm{BF}(p=0.016)$ and $\mathrm{FM}(p=$ $0.038)$, with a significant increase in $\operatorname{LBM}(p=0.006)$, while not showing any significant changes $(p \geq 0.05)$ in $\mathrm{BM}(p=$ $0.979)$ and BMI $(p=0.992)$. The CG, however, did not produce any significant $(p \geq 0.05)$ changes in any of the tested anthropometric variables (BM: $p=0.266$; BMI: $p=$ 0.123 ; $\% \mathrm{BF}: p=0.516$; FM: $p=0.937$ and LBM: $(p=0.522)$ 
Table 2: Pre- and post-test muscular strength and endurance changes in the mat Pilates and non-exercising control groups

\begin{tabular}{|c|c|c|c|c|c|c|}
\hline & \multicolumn{3}{|c|}{$\begin{array}{l}\text { Non-exercising control group (CG) } \\
\qquad n=25\end{array}$} & \multicolumn{3}{|c|}{$\begin{array}{l}\text { Mat Pilates programme group (IG) } \\
\qquad \mathrm{n}=\mathbf{2 5}\end{array}$} \\
\hline & Pre-test & Post-test & $p$-value & Pre-test & Post-test & $p$-value \\
\hline Body mass (kg) & $75.19 \pm 14.8$ & $72.03 \pm 19.76$ & 0.266 & $71.71 \pm 14.92$ & $71.70 \pm 14.68$ & 0.979 \\
\hline Body mass index $\left(\mathrm{kg} \cdot \mathrm{m}^{-2}\right)$ & $29.32 \pm 5.44$ & $29.15 \pm 5.48$ & 0.123 & $28.32 \pm 6.77$ & $28.32 \pm 6.64$ & 0.992 \\
\hline Body fat percentage $(\%)$ & $32.22 \pm 5.93$ & $32.46 \pm 5.79$ & 0.516 & $33.85 \pm 6.67$ & $32.23 \pm 5.82$ & $0.016^{*}$ \\
\hline Fat mass $(\mathrm{kg})$ & $24.88 \pm 8.66$ & $24.85 \pm 8.38$ & 0.937 & $25.03 \pm 9.53$ & $23.69 \pm 8.06$ & $0.038^{*}$ \\
\hline Lean body mass (kg) & $50.32 \pm 7.08$ & $49.86 \pm 7.45$ & 0.522 & $46.67 \pm 6.33$ & $48.04 \pm 7.52$ & $0.006 *$ \\
\hline
\end{tabular}

Values are means \pm standard deviation $( \pm \mathrm{SD})$; *: indicates significant difference from pre- to post-test $(p \leq 0.05)$

after completion of the eight-week Pilates programme (Table 2).

\section{DISCUSSION}

Results obtained from the present study indicate that eight weeks of mat Pilates produced improvements in \%BF, FM and LBM. This is of particular importance as mat Pilates may contradict or even reverse some of the most serious consequences of ageing; the loss of LBM (sarcopenia) can lead to major functional impairment, morbidity and mortality (22) whereas the normalization or reduction of increased body fat reverses the obesity-associated morbidities, such as hypertension, glucose intolerance, dyslipidaemia and fatty liver diseases (1).

The results obtained in the present study, following a period of Pilates training, are supported by Jago et al (14), Kloubec (23), Rogers and Gibson (24), Segal et al (25) and Sekendiz et al (26) who found non-significant changes in $\mathrm{BM}$, following durations of four weeks to six months of Pilates training in various age groups. Similarly, Jago et al (14), Kloubec (23) and Sekendiz et al (26) also found nonsignificant changes in BMI, following durations from four weeks to 12 weeks of Pilates training in various age groups. However, Rogers and Gibson (24) found a significant decrease from $23.5 \pm 5.0 \%$ to $22.3 \pm 4.0 \%$ in $\% \mathrm{BF}$, following eight weeks of Pilates training in adults, while the Sekendiz et al (26) study demonstrated no significant changes in \%BF following five weeks of Pilates training in sedentary adult women. Similar to this contradiction was the non-significant changes observed in FM and LBM (25), following six months of Pilates training in subjects older than 18 years of age.

The lack of change in BMI is as a result of the unchanged BM found in the present study as stature did not change at post-test. In turn, the lack of change found in BM could be attributed to insufficient training volume and intensity as the present study's training volume and intensity is even lower compared to previous research which also found non-significant changes in both BM and BMI. In the present study, the IG exercised three times per week for eight weeks which is less when compared to the five times per week subjects trained in the study by Jago et al (14) and less than the 12-week duration in the Kloubec (23) study. The present study only utilized a beginner mat Pilates pro-gramme, increasing in the number of repetitions and sets, while the Rogers and Gibson (24) study progressed from beginner to more advanced programmes. However, in the present study, FM significantly decreased, while LBM sig-nificantly increased in the IG, therefore creating the pos-sibility that training volume and intensity cannot be con-sidered a sole factor for the unchanged BM as indicated in this study.

The improvements in FM, LBM and \%BF observed in the present study could have been due to a change in skinfold thickness. This is since skinfolds obtained from subcutaneous fat tissue is based on the assumption that, as an individual gains adipose tissue, the increase in skinfold thickness will be proportional to the additional weight gain (27). The present study did not consist of any aerobic endurance exercises, but utilized own body weight and gravitational forces as means of resistance and thus, strength training. Also, the intensity of the programme increased in such a manner that a substantial amount of muscular endurance work was performed. Therefore, the significant improvements found in FM and LBM could be attributed to the muscular strength and muscular endurance training. Endurance exercises have been found to increase LBM by enhancing the capacity to oxidize fat by increasing the volume and function of mitochondria in skeletal muscles $(11,12)$, whereas resistance training decreases FM by increasing LBM (13), by means of muscle hypertrophy and stimulation of new bone growth and associated connective tissue $(28,29)$.

In conclusion, the present study indicates that eight weeks of mat Pilates programme produced significant improvements in \%BF, FM and LBM in elderly females. This is of particular importance as mat Pilates may contradict or even reverse some of the most serious consequences of ageing in elderly females as the loss of LBM (sarcopenia) can lead to major functional impairment, morbidity and mortality (22). In addition, the normalization or reduction of increased body fat reverses the obesity-associated morbidities, such as hypertension, glucose intolerance, dyslipidaemia and fatty liver diseases (1). 


\section{ACKNOWLEDGEMENTS}

The authors would like to thank the Tshwane University of Technology (TUT), South Africa, for their approval and financial support as well as the International Physical Activity Projects (IPAP) for their endorsement of the study and financial and statistical support.

\section{REFERENCES}

1. Oh S, Kim KS, Chung JS, Shong M, Park SB. Anti-obesity agents: a focused review on the structural classification of therapeutic entities. Cur Topics Med Chem 2009; 9: 466-81.

2. Perisinotto E, Pisent C, Sergi G, Grigoletto F, Enzi G. Anthropometric measurements in the elderly: age and gender differences. $\mathrm{Br} \mathrm{J}$ Nutr 2002; 87: 177-86

3. Bartali B, Benvenuti E, Corsi AM, Bandinelli S, Russo CR, Di Iorio A et al. Changes in anthropometric measures in men and women across the life-span: findings from the INCHIANTI study. Sozial- und Präventivmedizin 2002; 47: 336-48.

4. Folsom AR, Kushi LH, Anderson KE, Mink PJ, Olson JE, Hong C et al. Associations of general and abdominal obesity with multiple health outcomes in older women. Arch Internal Med 2000; 160: 2117-28.

5. Hughes VA, Roubenoff R, Wood M, Frontera WR, Evans WJ, Fiatarone Singh MA. Anthropometric assessment of 10 -y changes in body composition in the elderly. Am J Clin Nutr 2004; 80: 475-82.

6. Lei SF, Liu MY, Chen XD, Deng FY, Lv JH, Jian WX et al. Relationship of total body fatness and five anthropometric indices in Chinese aged 20-40 years: different effects of age and gender. Eur J Clin Nutr 2006; 60: 511-8.

7. Nessel EH. The physiology of aging as it relates to Sports. Am Med Athletic Assoc J 2004; 17: 12-17.

8. Nakagawa T, Hattori M, Harada K, Shirase R, Bando M, Okano G. Age-related changes in intramyocellular lipid in humans by in vivo $1 \mathrm{~h}$ mr spectroscopy. Gerontol 2007; 53: 218-23.

9. Suriah AR, Zalifah MK, Zainorni MJ, Shafawi S, Mimie Suraya S, Zarina $\mathrm{N}$ et al. Anthropometric measurements of the elderly. Mal J Nutr 1998; 4: 55-63.

10. Ballard JE, Wallace LS, Holiday DB, Herron C, Harrington LL, Mobbs $\mathrm{KC}$ et al. Evaluation of differences in bone-mineral density in 51 men age 65-93 years: a cross-sectional study. J Aging Phys Activity 2003; 11: $470-86$.

11. Borer KT. How effective is exercise in producing fat loss? Kinesiol 2008; 40: 126-37.

12. Irwin ML, Alvarez-Reeves M, Cadmus L, Mierzejewski E, Mayne ST, $\mathrm{Yu} \mathrm{H}$ et al. Exercise improves body fat, lean mass, and bone mass in breast cancer survivors. Obes 2009; 17: 1534-41.
13. Shaw BS, Shaw I, Brown GA. Resistance training and its effect on total, central and abdominal adiposity. SAJRSPER 2009; 31: 97-108.

14. Jago R, Jonker ML, Missaghian M, Baranowski T. Effect of 4 weeks of Pilates on the body composition of young girls. J Prev Med 2006; 42: 177-80.

15. Bertolla F, Baroni BM, Leal ECP Junior, Oltramari JD. Effects of a training program using the Pilates method in flexibility of sub-20 indoor soccer athletes. Rev Bras Med Esporte 2007; 13: 198e-202e.

16. Bernardo LM. The effectiveness of Pilates training in healthy adults: An appraisal of the research literature. J Bodywork Mov Therapies 2007; 11: 106-10.

17. Norton K, Olds T, eds. Anthropometrica. Sydney: University of New South Wales Press; 1996.

18. Durnin JVGA, Womersley J. Body fat assessed from total body density and its estimation from skinfold thickness: measurements on 481 men and women aged from 16 to 72 years. Br J Nutr 1974; 32: 77-97.

19. Siri WE. Body composition from fluid spaces and density. Berkeley, CA: University of California; 1956.

20. Reilly JJ, Murray LA, Wilson J, Durnin JVGA. Measuring the body composition of elderly subjects: a comparison of methods. Br J Nutr 1994; 72: 33-44.

21. Worth Y. Need to know Pilates? All the tips and techniques you need to get a toned, flexible body. London: Collins; 2004.

22. Bales CW, Ritchie CS. Sarcopenia, weight loss, and nutritional frailty in the elderly. Ann Rev Nutr 2002; 22: 309-23.

23. Kloubec JA. Pilates for improvement of muscle endurance, flexibility, balance, and posture. J Stren Cond Res 2010; 24: 661-7.

24. Rogers K, Gibson AL. Eight-week traditional mat Pilates-trainingprogramme effects on adult fitness characteristics. Phys Edu Recre Dance 2009; 80: 569-74

25. Segal NA, Hein J, Basford JR. The effects of Pilates training on flexibility and body composition: an observational study. Arch Phys Med Rehab 2004; 85: 1977-81.

26. Sekendiz B, Altun O, Korkusuz F, Akýn S. Effects of Pilates exercise on trunk strength, endurance and flexibility in sedentary adult females. J Bodywork Mov Therapies 2007; 11: 318-26.

27. Thompson DL. Fitness professional's handbook. $5^{\text {th }}$ ed. Champaign, IL: Human Kinetics; 2007.

28. Conroy B, Earle RW. Essentials of strength training and conditioning: National strength and conditioning association. $2^{\text {nd }}$ ed. Champaign, IL: Human Kinetics; 2000.

29. Wilmore JH, Costill DL, Kenney WL. Physiology of sport and exercise. $4^{\text {th }}$ ed. Champaign, IL: Human Kinetics; 2008. 